\title{
Expected Difference, Equity Nature and the Corporate Control Agreement Transfer Failed - the Evidence from China
}

\author{
Xiaodong Li \\ School of accounting, ZhengZhou Institute of Aeronautical Industry Management, Zhen Zhou, China. \\ Email: 1xdlls74@yahoo.com.cn
}

Received November $1^{\text {st }}, 2010$; revised December $24^{\text {th }}, 2010$; accepted December $29^{\text {th }}, 2010$.

\begin{abstract}
This paper has researched the issue of corporate control transfer failed in china capital market, which is completely different from existing studies in corporate control transfer field. The conclusion has shown that corporate control transfer very likely fails when there is a great difference between two sides of deals. And the equity nature is another affection factor. The corporate control transfer is not likely to fail when the equity nature is state-owned. The conclusion implies that we should make more improvement for institutions of corporate control transfer, because of the lack of market voluntary trade rule in china capital market.
\end{abstract}

Keywords: Expected Difference, Equity Nature, Corporate Control Agreement Transfer

\section{Introduction}

There are "free-ride" and "non-efficiency" defects in the market of corporate control transaction, while the market plays an important role in improving the agent problem for listed company. But the agreement transfer of corporate control can improve the two defects. The "free-ride" problem will block the company's voting efficiency, because the cost of proxy fight is afford by part of shareholder, but the benefit is shared by all shareholders [1]. So, the agreement transfer of corporate control can provide more trade free for control shareholder. That will prevent the small shareholder's "free-ride", and it is more easily for the accomplished of corporate control transfer [2].

In this paper, the agreement transfer fail of corporate control is defined that the two sides of merging has a intention deal for corporate control transfer, but the deal is not actually accomplished finally. Many of researchers had researched corporate control agreement transfer in different fields, like as operating performance after merging, market effect, the feature of merging company, the price of merging, and the mode of control transfer etc. [2]. But the reason of corporate control agreement transfer fail is not concerned about. In this paper, the reason of corporate control agreement transfer fail is the re- searched subject which is neglected by most current studies.

Section 2 review of the literature and develop the hypothesis. Section 3 designs the research method and sample selecting. Section 4 examines the relationship between the expected difference and the transfer failed of corporation control. Section 5 concludes.

\section{Therotical Discussion and Hypothesis Development}

In essence, the transfer of corporate control is the transfer of decision-making power. The efficiency of transfer price negotiations and the constraints of institutions environment are key factors that influence the result of corporate control transfer. Jensen and Meckling believe that the transfer of decision-making power based on market participants voluntary transaction, can match well the knowledge and decision-making power [3]. It is benefit for economics efficiency. If the two side traders have great difference about the future expectation of corporate, the transfer deal will not easily to success, and most likely to fail. Farther, the transfer of corporate control is not only effect by price negotiation, but also affected by institutions environment. Such as, the transfer of corporate control has deeply influenced by administra- 
tive intervention in china capital market. Therefore, there are two views to explain the reason of corporate control transfer fail. The first is the market trade influence, i.e., the great differences of traders will significant influence the result of corporate control transfer. The second is institutions constraint, i.e., the exogenous institutional environment has the function to enhance or to block the process of corporate control transfer.

On the one hand, if the trade of corporate control is based on market voluntary transaction system, the traders' large difference which caused the different future expectation of corporate control income could block the processing of corporate control transfer. Despite the agreement transfer of corporate control has a framework in beginning, but the detail of the trade has not been determined, further, both sides of trade must negotiate all of the issues of corporate control transfer. Therefore, the differences of the expectation income of corporate control become a crux factor that affect the success of corporate control transfer, because the great differences of expectation income will result in the difference of transaction price. In capital market, for a certain stock, the changing of stock price is partly reflected the difference of future expectation income of the listed company. If stock price has more synchronicity with the market index, that meaning the firm-specific information has little enter the decision of market participants [4], i.e., the private information of listed companies has less concerned by investors. So, for this kind of corporation, the differences of future expectation income are not likely being great, same is the difference of transaction pricing. Roll is the first researcher who note that the influence of firm-specific information to stock price. He divided the stock return into system risk return and specific return, former is the market return, and the latter is firm-specific risk return which has captured a part of stock return which couldn't explained by market public information, i.e., the affection of private information on stock return. For the classical regression model of stock return, if stock price more dependent on the firm-specific information, then the residual of regression model would be greater and the less adjusted $\mathrm{R}^{2}$ of regression model would be [5]. Similarly, Durnev's researching has shown that the more adjusted $\mathrm{R}^{2}$ is, the more related between stock return and the firm future income, i.e., the lower adjusted $\mathrm{R}^{2}$ has shown that the stock price has absorbed more firm-specific information [6]. For the heterogeneous noise, while it can weaken the capability of stock price reflecting firm future income, but it has little effect on stock price synchronicity. So the firm-specific information is still a main factor to affect the stock price [7]. Ferreira and Laux noted that good corporate governance would less its anti-takeover provisions, and that is benefit for its private information using by investors, thereby enhancing its risk characteristics [8].

In summary, the firm's specific risk could be boosted when market investors are more concern the private information of listed company. Accordingly, the investors expected deference of the company future value will increase. If the expected difference become to the extent of that it can not be negotiate. The agreement transfer of corporate control is most likely to fail. Therefore, the author proposes the first hypothesis.

H1: the investors expected difference is a crux factor which affects the process of corporate control transfer, when there is a great difference between two sides of trader, the agreement transfer of corporate control would likely be to fail.

On the other hand, the agreement transfer of corporate control is deeply affected by the circumstance of institutions. The institutions constraints could result in the phenomenon of vote-right heterogeneity. Hart believes that the voting structure of one shares one vote system is a crucial fundamental to ensure the transfer efficiency of corporate control [1]. Although it has shown the character of one shares one vote in china capital market, but most corporate control transfers is not based on the market voluntary trade mechanism. The administrative intent is a crucial role in china capital market. Therefore, voteright heterogeneity is a general phenomenon in china capital market. For different equity nature of corporate control transfer, the focus of administrative supervising is different. Despite the supervising procedure of stateowned equity transfer is more complex than others. But which doesn't mean that state-owned equity transfer more difficult than nonstate-owned equity transfer. Because it has shown strong administrative intention that state-owned equity transfer, then, those deals are immune from the price dispute and the payment method. In the counter cases, the nonstate-owned equity transfer is affected by price dispute and payment method, and if the difference couldn't be coordinated, then the corporate control transfer is most likely to fail. Therefore, the author proposes the second hypothesis.

$\mathrm{H} 2$ : the equity nature is another factor which affects the progress of corporate control transfer. For the case of state-owned equity transfer, the deal of corporate control transfer is not likely to fail.

\section{Researching Design}

\subsection{Sample Selection}

Since 1990s, it has gone three stages for corporate M\&A (merge and acquisition) in china capital market. First stage is the initial phase (1993-1996), in which period the objective of M\&A is to improve the poor performance of 
state-owned firms. The second stage is development phase (1997-2005), in which period the objective of M\&A is to protect and to acquire the "shell" resource because of the scarcity of qualification in china capital market. The third stage is maturity phase (after 2006), in which period the objective of M\&A is changed from financial purpose to industry strategic plan [9]. In this paper, to exclude the specific influence of first and second stages, our researching is focus on the third stage.

The samples are selected by following steps: first, we select all cases of corporate control agreement transfer in china capital market since September 1, 2006. Second, we eliminate the cases which has no statement date for corporate control transfer success, because it is difficult to judge the consequence of corporate control transfer. Third, we eliminate the cases which part of the researching data is unobtainable. Finally, we have acquired 394 effective samples. All data are collected from the CSMAR database.

\subsection{Researching Model and Variables}

According to the above mentioned hypothesizes, we set up the following model to verify our speculation.

$$
\begin{aligned}
\text { success }_{i}= & \alpha+\beta_{1} \text { difference }_{i}+\beta_{2} \text { sharenature }_{i} \\
& +{\text { control var } s_{i}+\varepsilon_{i}}
\end{aligned}
$$

where the success denotes the consequence of corporate control transfer, if the transfer is failed then the success variable value is 0 otherwise is 1 . The difference denotes the extent of traders expected difference. The sharenature denotes the nature of corporate equity, if the sample corporate is state-owned, then the value is 1 , otherwise is 0 . The controlvars denotes other control variables.

Based on the Section 2 of this paper, the adjusted $\mathrm{R}^{2}$ of sample stock return regression to the market return can partly represent the difference of traders anticipation of listed company. Therefore, we use the adjusted $\mathrm{R}^{2}$ to represent the expected difference variable. The greater adjusted $\mathrm{R}^{2}$ imply great expected difference, and the lesser adjusted $\mathrm{R}^{2}$ imply less expected difference. We calculate all of the adjusted $\mathrm{R}^{2}$ of 394 samples one by one. The regression model of adjusted $\mathrm{R}^{2}$ is as following:

$$
r_{i t}=\alpha+\beta r_{m t}+\varepsilon_{i t}
$$

where, $r_{i t}$ is the real stock return calculated by monthly, the period is 12 . And $r_{m t}$ is the same period market return.

In addition, there are different market characteristics between Shanghai Stock Exchange and the Shenzhen Stock Exchange. Those two markets have different regulation mechanism, for example, the Shenzhen Stock Exchange is the first market to score the listed company's information disclosure, and has established the credit file of listed company. So, the level of investors using the firm-specific information must have difference. Therefore, in this paper, besides the adjust $\mathrm{R}^{2}$ of all samples enter the regression model, we add in a new variable which is cross variable of market type (Shanghai and Shenzhen, if the market type is Shanghai, then the value is 1 , otherwise is 0 ) and adjusted $R^{2}$.

For the control variables, we selected the financial lever and the payment method and the industry factor. In the process of M\&A, the creditors are playing an important role, because they have the rights conferred by contract law to claim the transfer contract invalid, and creditors exercising the right would block the deal of M\&A. For the payment methods, there are three main methods: cash, and share, and convertible bonds. Because the cash payment is more difficult for buyer than other methods, so in our model, if the payment method is cash then the variable value is 1 , otherwise is 0 . In addition, according to the china antitrust law, the industry factor must be concerned in this researching field, so this paper has controlled the industry variable.

\subsection{The Results of Descriptive Statistic}

The variables results of all samples have provided in Tables 1 and 2. The ratio of corporate control agreement transfer failed is 9.6 percent in all 394 samples. That means the agreement transfer is efficient in corporate control transfer. In Table 1, the equity nature variable has a significantly different for two group samples, but the expected difference variable does not. However, in Section 4 of this paper, we will add in the cross variable which is taking into account the difference characteristic of two stock market (Shanghai and Shenzhen).

In Table 2, the expected difference has significantly different between the state-owned group and the nonstate-owned group. This implies that there is more private information concerned in pricing for nonstateowned corporate stock. In Table 3, the simple correlation coefficient has been provided. The results have initially proved the hypothesis above mentioned.

\section{The Results of Multiple Regressions}

We use the logistic model to examine the samples data, if the corporate control transfer successful then the dependent variable's value is 1 , otherwise is 0 . As the Table 4 shown that the researching hypotheses have been proved. For the single variable of expected difference, there are no significantly coefficient in model 1 and model 3, but in model 1 and model 3 the cross variable of expected difference and market type has a significantly positive coefficient. This result implies that there are obviously different characteristic in Shanghai market and 
Table 1. The variables description of successful group and failed group.

\begin{tabular}{|c|c|c|c|c|c|c|}
\hline Group & $\mathrm{n}$ & variable & mean & median & $\min$ & $\max$ \\
\hline \multirow{4}{*}{ success } & \multirow{4}{*}{$\begin{array}{c}356 \\
90.4 \%\end{array}$} & Expected difference & 0.3984 & 0.4155 & -0.10 & 0.92 \\
\hline & & Equity nature & 0.4860 & 0 & 0 & 1 \\
\hline & & Financial lever & 0.5796 & 0.5381 & 0.02 & 10.03 \\
\hline & & Payment method & 0.9326 & 1 & 0 & 1 \\
\hline \multirow{4}{*}{ fail } & \multirow{4}{*}{$\begin{array}{c}38 \\
9.6 \%\end{array}$} & Expected difference & 0.4019 & 0.4320 & -0.10 & 0.88 \\
\hline & & Equity nature & 0.1842 & 0 & 0 & 1 \\
\hline & & Financial lever & 0.6876 & 0.5788 & 0.07 & 5.40 \\
\hline & & Payment method & 0.9474 & 1 & 0 & 1 \\
\hline
\end{tabular}

Table 2. The variables description of state-owned group and nonstate-owned group.

\begin{tabular}{|c|c|c|c|c|c|c|}
\hline group & $\mathrm{n}$ & variables & mean & median & $\min$ & $\max$ \\
\hline \multirow{3}{*}{ State-owned } & \multirow{3}{*}{$\begin{array}{c}180 \\
45.7 \%\end{array}$} & Expected difference & 0.4378 & 0.4690 & -0.10 & 0.90 \\
\hline & & Financial lever & 0.5208 & 0.5464 & 0.02 & 1.07 \\
\hline & & Payment method & 0.9167 & 1 & 0 & 1 \\
\hline \multirow{3}{*}{ nonstate-owned } & \multirow{3}{*}{$\begin{array}{c}214 \\
54.3 \%\end{array}$} & Expected difference & 0.3659 & 0.3845 & -0.10 & 0.92 \\
\hline & & Financial lever & 0.6483 & 0.5367 & 0.07 & 10.03 \\
\hline & & Payment method & 0.9486 & 1 & 0 & 1 \\
\hline
\end{tabular}

Table 3. The simple correlation coefficient (spearman onetailed test).

\begin{tabular}{ccccc}
\hline & success & $\begin{array}{c}\text { Expected } \\
\text { difference }\end{array}$ & $\begin{array}{c}\text { Cross } \\
\text { variable }\end{array}$ & $\begin{array}{c}\text { Equity } \\
\text { nature }\end{array}$ \\
\hline success & 1 & & & \\
$\begin{array}{c}\text { Expected } \\
\text { difference } \\
\text { Cross } \\
\text { variable }\end{array}$ & -0.007 & 1 & & \\
Equity nature & $0.179 * * *$ & $0.146^{* * *}$ & $0.118^{* * *}$ & 1 \\
\hline
\end{tabular}

***represent significant level under $1 \%$, **represent significant level under $5 \%$.

Shenzhen market. Therefore, the hypothesis 1 has been proved only in Shanghai market, but in pool samples of two markets we had not found the evidence of the positive correlation between expected difference and corporate control transfer failed.

For the variable of equity nature, our researching has founded that the agreement transfer of corporate control is not likely to fail when the corporate is a state-owned, while the nonstate-owned corporate control transfer is more easily failed. This result has been proved according to the model 2 and model 3 in Table 4. Further, we can draw the conclusion that it is based on voluntary trade rule for nonstate-owned corporate control transfer. Because it is play a very important role that expected difference of traders in such deals. When the expected difference is great enough, the deal would be failed, i.e., in state-owned corporate control transfer, the administrative intention is more important than nonstate-owned corporate control transfer, and the administrative authority is the decisive factor affected the success or fail of corporate control transfer.

Finally, we had made a robust testing for this researching. The binary dependent variable of corporate control transfer has been substituted by the duration of M\&A negotiation period. If there are great differences between two side traders, then the period of negotiation is likely extended until there are no opposite opinions about this deal. The result of robust testing is consistent with above conclusion, i.e., the more great expected difference is, the more negotiation time will spend. And the equity nature variable has the same evidence.

\section{Conclusions}

In this paper, the agreement transfer of corporate control has been researched which is focused on the expected difference of traders and the equity nature. This researching view is totally different from existing resear- 
Table 4. The results of logistic regression.

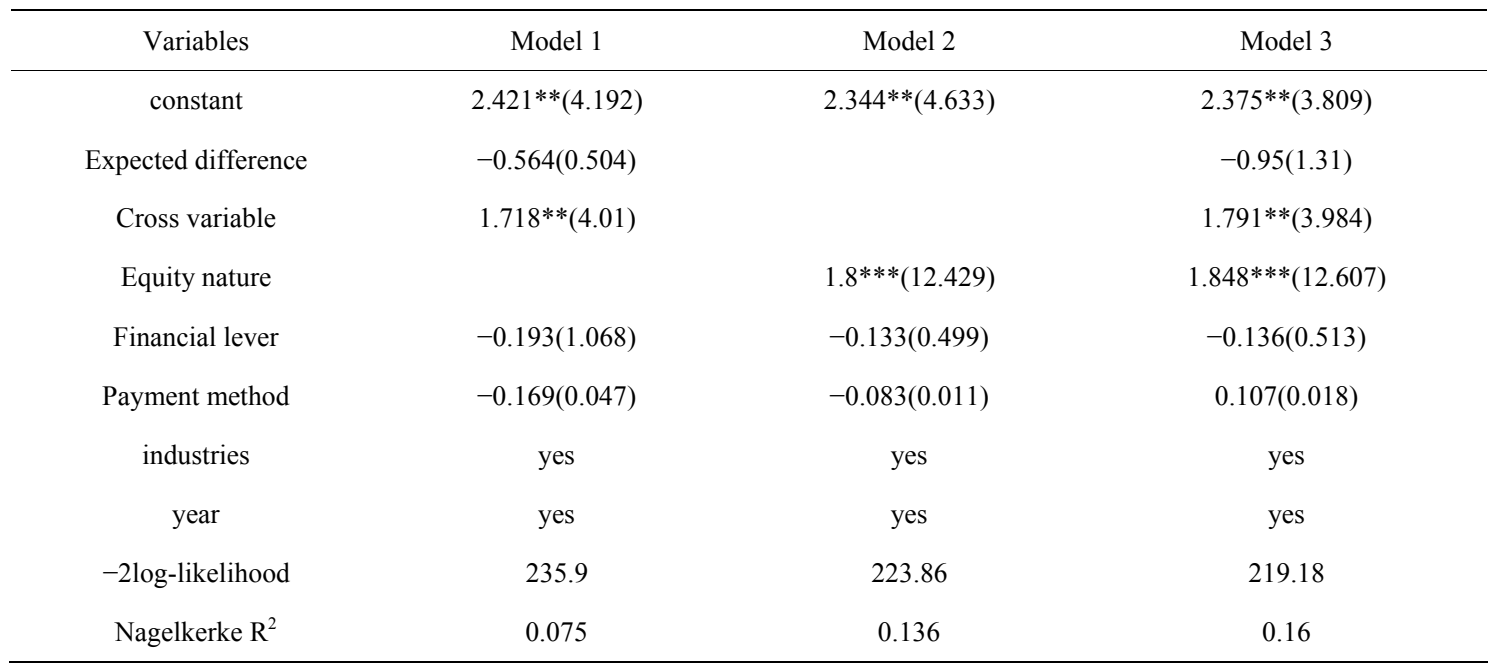

Which is the WALD value in brackets, *** represent significant level under $1 \%$, ** represent significant level under $5 \%$. Model 1 , model 2 and model 3 is that expected difference, cross variable and equity nature variable enter into the regression model respectively.

ches which were mostly concern the market effective and operating performance of M\&A. Our research has drawn the conclusions that the process of corporate control agreement transfer is significantly affected by the expected difference of traders in Shanghai capital market, i.e., the greater differences of traders expect is, as the consequence, the higher probability of M\&A failing will be. Furthermore, when the controlling shareholders are state-owned, then the agreement transfer deal of corporate control is unlikely to fail. This conclusion has shown that there is lack of the voluntary trade rule in stateowned corporate control transfer cases.

To improve the efficiency of capital market transactions, the voluntary trade rule is most importantly basic conditions abided by all market exchanges. So the mechanism of corporate control agreement transfer must be consistent with the voluntary trade rule. But the corporate control agreement transfer is still in an imperfect circumstance of china capital market, which can be inferred clearly according this paper's conclusion. In which institution circumstance, the voluntary trade rule is ignored, that is harmful for the market exchange efficiency. Therefore, we must radically improve the provisions of agreement transfer of corporate control to avoid the involvement of non-market factors. Thus the method of equity exchange, which is the agreement transfer of corporate control, will notable enhance the efficiency of resource allocation of china capital market.

\section{Acknowledgements}

This paper been funded of the humanity and social science project of China Education Ministry (10YJC790148), and the Young Teacher project of Henan province (2010 GGJS-144).

\section{REFERENCES}

[1] O. Hart, "Firms, Contracts and Financial Structure," GeZhi Press, 1998, pp. 233-256.

[2] S. M. Li and Y. C. Zhang, "Institutional Environment, Transaction Rule and Efficiency of Corporate Control Transfer," Journal of Economics Research, Vol. 5, 2009, pp. 92-105.

[3] Hart et al., "Contract Economics," Economics Science Press, 1999, pp. 319.

[4] J. X. You and J. S. Zhang and W. Jiang, "Institution Building, Firm-Specific Information and the Synchronicity of Stock Prices: A R2 Based Perspective," China Economic Quarterly, Vol. 6, No. 1, October, 2006, pp. 189206.

[5] Roll and Richard, " $\mathrm{R}^{2}$," Journal of Finance, Vol. 43, No. 3, 1988, pp. 541-566.

[6] A. Durnev, R. Morck, B. Yeung and P. Zarowin, "Does Greater Firm-Specific Return Variation Mean More or Less Informed Stock Pricing," Journal of Accounting Research, Vol. 41, No. 5, 2003 , pp. 797-836. doi:10.1046/j.1475-679X.2003.00124.X

[7] Z. Z. Yuan and X. F. Ju, "The Validity Test of Stock Price Non-Synchronicity Method Used to Measure Stock Price Informativeness Based on Panel Data Model," Journal of China Soft Science, Vol. 3, 2009, pp.174-185

[8] M. Ferreira and P. Laux, "Corporate Governance, IdioSyncratic Risk, and Information Flow," Journal of Finance, Vol. 62, No. 2, 2007, pp. 951-989. doi:10.1111/j.1540-6261.2007.01228.x

[9] X. Z Wu, "The Summary of M\&A Conference," Accounting Research, Vol. 2, 2010, pp. 89-91. 